\title{
Education and bioethics teaching in times of pandemic
}

\author{
A educação e o ensino de bioética em época de pandemia
}

\author{
Waldemar Antônio das Neves Júnior ${ }^{1}$ (1) | waldemarneves@hotmail.com \\ Lumaira Maria Nascimento Silva da Rocha Marques' (1) lumaira_@hotmail.com \\ Michelle Cecille Bandeira Teixeira² (D) michelle.cecille@gmail.com
}

\begin{abstract}
Introduction: Due to the suspension of face-to-face activities during the COVID-19 pandemic, Higher Education Institutions had to discuss and plan alternative actions in an attempt to readequate themselves to emerging educational demands in order to offer remote accessibility to the academic community and, consequently, reduce social and digital exclusion.

Development: Having that in mind, this article aims at offering a reflection on the teaching of bioethics under the perspective of social justice and education. Within this context, the students' socioeconomic profile cannot be ignored in the planning of online education, since it directly affects students' accessibility to academic activities through the use of computers and the internet. Therefore, this article proposes the use of moral intelligence skills as learning goals, in addition to revising and contextualizing pre-existing problems prior to the new reality of didactic contents. Moreover, it proposes a reflection on how bioethics may contribute to the discussions on the increase in social inequalities during this moment of crisis.
\end{abstract}

Conclusion: The reflections presented in this article can be used in both remote, face-to-face and hybrid teaching contexts.

Keywords: Teaching; Education; Bioethics; Online Teaching; Pandemic.

\section{RESUMO}

Introdução: Com as atividades presenciais suspensas em decorrência da pandemia, as instituições de ensino superior tiveram de discutir e executar o processo educativo e reinventar-se em relação ao processo educativo a ele, de modo a oferecer o acesso remoto e, ao mesmo tempo, amenizar a exclusão sociodigital.

Desenvolvimento: $O$ objetivo deste artigo é realizar uma reflexão propositiva para o ensino remoto da bioética sob o olhar da educação em valores e justiça social. O perfil socioeconômico dos discentes não pode ser ignorado quando se planeja a educação on-line, fato que impacta diretamente o acesso às aulas por meio de computadores e internet. O artigo propõe utilizar as capacidades da inteligência moral como objetivos de aprendizagem, revisar os problemas preexistentes, contextualizá-los à nova realidade dos conteúdos didáticos e refletir sobre como a bioética pode contribuir para as discussões sobre as desigualdades sociais que aumentaram de forma exponencial neste momento de crise.

Conclusão: As reflexões propositivas aqui apresentadas podem ser utilizadas no modelo de ensino remoto, presencial ou híbrido.

Palavras-chave: Ensino; Educação; Bioética; Ensino On-line; Pandemia.

${ }^{1}$ Universidade Federal de Alagoas, Maceió, Alagoas, Brazil.

${ }^{2}$ Universidade Federal Fluminense, Niterói, Rio de Janeiro, Brazil.

Chief Editor: Daniela Chiesa

Associate Editor: Daniela Chiesa

Received on 08/06/20; Accepted on 05/20/21.

Evaluated by double blind review process. 


\section{INTRODUCTION}

In March 2020, the World Health Organization (WHO) announced the pandemic of the new coronavirus (SARSCoV-2), leading to the adoption of several measures in an attempt to reduce the contamination curve of the world's population. One of them was the recommendation for social distancing, followed by social isolation, which, among other consequences, led to the need to interrupt activities in several sectors considered non-essential to society. Consequently, all educational institutions had their in-person classes suspended.

In Brazil, with the suspension of educational activities, the Ministry of Education (MEC) issued several ordinances, and the last one, N. 544, of June 17, 2020, authorized the replacement of disciplines that were taught in person by classes taught in digital environments, using information and communication technologies (ICTs) or other conventional means ${ }^{1}$.

Undoubtedly, despite the fact that Emergency Remote Learning (ERL) and Distance Learning (DL) are already a reality for some Higher Education Institutions (HEls), for countless others this has brought several challenges ${ }^{2}$. Universities in the health area had to reinvent themselves in relation to the educational process and, almost simultaneously, they have discussed and implemented the best options to offer remote access and alleviate both social and digital exclusion, aggravated by the pandemic.

The discipline of Bioethics also had to reinvent itself, since, in person, it is characterized by dialogic discussions and is often approached through active methodologies strategies or moral practices. How can we adapt the virtual teaching of Bioethics in times of pandemic without aggravating the inequities? This question guided our research, which resulted in the following objective: to carry out a purposeful reflection on remote teaching in Bioethics in times of pandemic, from the perspective of education concerning values and social justice.

\section{SOCIO-DIGITAL INCLUSION AND SOCIAL JUSTICE IN HIGHER EDUCATION IN TIMES OF PANDEMIC}

The contemporary discussion of education aimed at citizenship and values cannot be separated from the debate on the inclusion of a cultural, racial, ethnic, gender and social diversity in the university. This citizenship education, based on democratic, egalitarian and equitable assumptions, envisions a fairer society with pedagogical and curricular choices linked to values that are intrinsically related to the students' moral education.

The interiorization of public universities and the implementation of the affirmative actions through the quota system brought changes to the socioeconomic profile of medical students, which cannot be ignored when planning online education during the pandemic. A good example of this situation is Universidade de Campinas (UNICAMP), which has, since 2005, implemented the Affirmative Action and Social Inclusion Program (Paais, Programa de Ação Afirmativa e Inclusão Social), aiming at the inclusion of high school students from public schools. Since 2018, the Institution has observed a higher percentage of admission of brown and black students from the public school network ${ }^{3}$. In 2019, in the medical course of the same institution, it was found that this percentage reached $85 \%$, changing their socioeconomic profile, with a predominance of strata $\mathrm{C} 1$ and $\mathrm{B} 27^{3}$. A study with medical students at Universidade Federal da Bahia (UFBA) showed that $66.4 \%$ self-declared black and brown, $44.4 \%$ studied most of high school in public schools and $17.6 \%$ declared having a family income up to 3 minimum wages ${ }^{4}$. At the Universidade Estadual de Londrina (UEL), an analysis of the socioeconomic profile from 2004 to 2012 concluded that the most often declared family income was 7 to 10 minimum wages ${ }^{5}$. However, in 2013, they recorded a greater number of new medical students with a family income of 1 to 3 minimum wages ${ }^{5}$. Similar data were found at Universidade Federal do Pará (UFPA), where $30.9 \%$ of the medical students declared a family income of 1 to 3 minimum wages and $3.9 \%$ up to 1 minimum wage ${ }^{6}$.

Also, according to the UNICAMP survey during the pandemic, it was observed that the majority (80\%) of students accessed the classes via computer, notebook, or cell phone; that only $10 \%$ accessed classes exclusively by cell phone, and $10 \%$ accessed by tablet $^{3}$. The main accessibility problems were: unstable internet connection and/or access exclusively via mobile networks; greater difficulty in following activities transmitted through web conferences and virtual meetings, as well as difficulties in accessing activities on digital platforms and image applications ${ }^{3}$.

These data, although not generalizable, do not exclude the relevance of observing these students who entered an elite course, and who cannot be ignored when planning an online education. Mainly in a period in which social inequalities lead to a demand for more equitable choices, especially in educational institutions which, at their origin, cannot be an additional cause of exclusion for groups that are already socially oppressed. In all of them, but especially the higher education ones (the object of our research), must be committed to establishing a culture of inclusion and legitimization of diversity, training for citizenship, in an attempt to minimize inequalities and increase inclusion.

Equality is not exclusively related to the distribution of goods among individuals (such as, for instance, distributing mobile devices to socially vulnerable students and concluding that this isolated action would be the solution for the issue of remote access to education); equality is closely associated 
with social relations and processes ${ }^{7}$. The individuals are members of different social groups, whose experiences and opportunities are influenced by their connections and how these people interact, observing how oppression impacts different social groups.

Our reflection, from the perspective of equality in online education, assumes that individuals who are part of privileged or oppressed groups have their teaching and learning opportunities influenced by this association with a social group. Their specificities and oppression mechanisms, which may arise in the pedagogical and curricular choices of educational institutions, must be taken into account.

\section{EDUCATION CONCERNING VALUES AND THE TEACHING OF BIOETHICS}

We start from the point of view of bioethics teaching that is built in Latin America in critical contexts of inequality and social exclusion, aimed at building knowledge and practices that join philosophy, social sciences, humanities and health.

The field of Bioethics ${ }^{8}$ encompasses the social, economic, cultural and environmental dimensions, where discussions of the most diverse realities are established, such as prejudices, exclusion, ecology, among others, which are traversed by moral conflicts. One of the current challenges of the teaching of Bioethics is to contextualize the moral conflicts that already exist and the ones that were enhanced due to the pandemic, aiming to contribute to the discussion and reflection on fundamental topics for our current reality.

For Puig, "the articulation of significant moral problems treated with the moral intelligence tools and guided by moral culture constitutes an excellent experience of learning moral and values" ${ }^{\prime \prime}$. Therefore, one can autonomously face conflicts of value and controversies of unresolved issues that permeate the lives of individuals and groups in open, plural and democratic societies ${ }^{10}$.

Next, we will describe the skills that constitute the Moral Intelligence framework according to Puig ${ }^{11,12}$.

One of the purposeful reflections of this article is that these skills can be used as learning objectives in Bioethics disciplines and can be planned and stimulated in pedagogical strategies or in moral practices developed in the classroom, whether in-person or virtual ones.

Moral practices for Puig ${ }^{10}$ can be considered as: "an established course of cultural events that allows us to face significant, complex or conflicting situations from a moral point of view". Also, according to the author, moral practice is a means of teaching and learning that problematizes usual life situations; it is a situation that has been though of and willing to learn in social practice ${ }^{10}$. Later, we will establish its correlation with ERL and DL. It should be noted that from Puig's perspective, there is no possibility of moral construction without the presence of contextualized moral problems ${ }^{12}$.

\section{BIOETHICS TEACHING STRATEGIES IN A VIRTUAL ENVIRONMENT}

With the pandemic, the entire discussion about ERL and $\mathrm{DL}$, which would take decades, was accelerated due to its urgent attribute. This led the Ministry of Education (MEC) to authorize the replacement and adaptation of in-person disciplines into classes that use digital media, while the pandemic situation lasts ${ }^{1}$.

Before continuing our purposeful reflection on the teaching of Bioethics in a virtual environment, one needs to differentiate between ERL and DL. The DL modality occurs when students and teachers are not together at the same time ${ }^{14}$. The term ERL, on the other hand, refers to the rapid change

Table 1. Moral Intelligence Skills according to Puig.

Moral Intelligence Skills

Self-knowledge

Empathy

Moral judgment

Dialogical skills

Critical understanding

Self-regulation
Characteristics

Building and positively valuing the self, knowing oneself, integrating the biographical experience and project it into the future

Ability to adopt social perspectives; putting oneself in the other's place and recognizing the other's feelings, needs, opinions and arguments.

Development of moral sensitivity and the ability to think about moral problems in a fair and solidary way (care for others)

Ability to change your opinion and think about the points of view of other speakers, with the intention of coming to an understanding

Ability to acquire information and compare different points of view about reality, aiming to understand it better and commit to improving it

Seek coherence between judgment and moral action, acquiring desired habits and voluntarily build one's moral character

Source: Neves Júnior ${ }^{13}$ based on Puig ${ }^{11-12}$. 
of panoramas, with different needs and limitations, and which involves a temporary change due to the crisis circumstances ${ }^{14}$. This teaching modality is considered to be remote because it requires a temporary geographic distance between students and teachers and was adopted at different levels of education by educational institutions around the world, so that school activities were not interrupted in the midst of the pandemic ${ }^{15}$.

As part of the reflexive proposition, we can use, in Bioethics disciplines, moral practices that are related to the following skills: self-knowledge, empathy, moral judgment, dialogical skills, critical understanding and self-regulation.

In ERL, virtual classes can take place in what is called synchronous time (which may follow the principles of in-person teaching), using video classes, lectures via web conferencing system (for example, Zoom, Google Meet, RPN, etc.), and chatrooms $^{15-17}$. On the other hand, DL activities can also occur asynchronously during the week in the virtual learning environment (VLE), such as: Moodle, Teleduc, Blackboard ${ }^{15,17}$. It is of the utmost importance to emphasize that all activities, whether ERL or DL, must be prepared and planned, connecting the moral practice, the didactic contents and the desired learning objectives in order to facilitate moral training.

According to Maluf and Garrafa ${ }^{18}$,"one of the pedagogical difficulties for the development of Bioethics as a discipline is the construction of its contents, how it should be structured, how it should be defined in terms of mastering the theoreticalpractical concepts and its objectives".

Therefore, another purposeful reflection is an attempt to contextualize the didactic contents. For that purpose, we merged some suggestions of topics proposed by the Bioethics Core Curriculum (Programa de Base de Estudos sobre Bioética) developed by UNESCO ${ }^{19}$, by the Teaching and Research Group in Bioethics (GEPBio, Grupo de Ensino e Pesquisa em Bioética) ${ }^{20}$, as well as other programs that we consider to be relevant for the discussion of the disciplines in Bioethics. As a result, in addition to the issues that have already been discussed in the curriculum, we also mention: human dignity; human rights; respect for human vulnerability and personal integrity; equality, equity and social justice and their direct relations with the following contents: race, gender, homeless population, indigenous population and quilombolas, slums, LGBT community, especially transgender people; research involving human beings; allocation of health resources; telemedicine; judicialization in health; environmental protection; the biosphere and biodiversity; basic sanitation ${ }^{19,20}$.

Some of the disciplines already held these discussions in their syllabuses; what is needed now is to discuss in medical courses how to advance the discussion for the insertion of the several spectra of human diversity - biological, subjective, ethnic-racial, gender, sexual orientation, socioeconomic, political, environmental, cultural, ethics - provided for in the National Curriculum Guidelines (NCGs) ${ }^{21}$. It is necessary to improve this debate on the social responsibility of medical schools, not only in this period of pandemic, but in the sense of promoting social justice to reduce inequities ${ }^{21}$. All these topics should be contextualized within the current moment, as well as adapt the discussions of content that already existed before the pandemic in the curricula, such as: the beginning and end of human life, principles of bioethics, secrecy and confidentiality, and professional relationship with the patient.

Added to these attempts to readjust the teachinglearning content and objectives, it is also necessary to discuss the socio-digital inclusion strategies with the teaching staff and the HEls. It is noteworthy that these measures cannot be eventual and understood as a solution for the question of remote access to education; close and continuous monitoring of the students identified as being in a situation of social vulnerability is essential, so that they can be offered pedagogical, emotional, socioeconomic and digital support.

\section{FINAL CONSIDERATIONS}

The Covid-19 pandemic, due to its urgent nature, accelerated the inclusion of remote teaching in education, but, at the same time that it brought advances regarding the inclusion of information and communication technologies for the curricula in the health area, it also brought many uncertainties. For the discipline of Bioethics, it was no different, not only regarding education questions about socio-digital, economic and health inequalities, but also in learning, due to the loss of contact and face-to-face discussions, essential for the construction of moral personality. The challenge now is to incorporate the learning objectives consistent with moral practices and contents in Bioethics disciplines and maintain dialogical and participatory skills in the virtual environment.

We hope that our purposeful reflections can contribute to new considerations on the teaching of Bioethics, so that we can envision the exponentially increased bioethical problems and dilemmas in society at this time of pandemic, under the lens of social justice and, thus, assist the moral development of our students.

\section{AUTHORS' CONTRIBUTION}

Waldemar Antônio das Neves Júnior was in charge of the study concept, data curation, formal analysis, investigation, methodology and writing of the manuscript.

Lumaira Maria Nascimento Silva da Rocha Marques and Michelle Cecille Bandeira Teixeira participated in the investigation, methodology, writing and content review of the manuscript. 


\section{CONFLICT OF INTERESTS}

The authors declare no conflicts of interest.

\section{SOURCES OF FUNDING}

The authors declare no sources of funding.

\section{REFERENCES}

1. Brasil. Portaria n 544, de 16 junho de 2020. Dispõe sobre a substituição das aulas presenciais por aulas em meios digitais, enquanto durar a situação de pandemia do novo coronavírus - Covid-19 [access in 17 jun 2020]. Available from: http://www.in.gov.br/en/web/dou/-/portaria-n544-de-16-de-junho-de-2020-26192487.

2. Martelli Júnior $H$, Machado RA, Swerts MSO, Martelli DRB, Caldeira AP. The works of Hercules and Covid-19 lessons for medical education. Rev Bras Educ Med. 2020;44(3):e084 [access in 28 jul 2020]. Available from: https://www.scielo.br/scielo.php?script=sci_arttext\&pid=S0100$55022020000300603 \&$ lng $=$ pt\&nrm=iso\&tlng=en.

3. Appenzeller S, Menezes FH, Santos GG, Padilha RF, Graça HS, Bragança JF. Novos tempos, novos desafios: estratégias para equidade de acesso ao ensino remoto emergencial. Rev Bras Educ Med. 2020;44(sup.1):e0155 [access in 20 dec 2020]. Available from: https://www.scielo.br/pdf/rbem/ v44s1/1981-5271-rbem-44-s1-e155.pdf.

4. Veras RM, Fernandez CC, Feitosa CCM, Fernandes S. Perfil socioeconômico e expectativa de carreira dos estudantes de Medicina da Universidade Federal da Bahia. Rev Bras Educ Med. 2020;44(2):e056 [access in 3 oct 2020]. Available from: https://www.scielo.br/pdf/rbem/v44n2/1981-5271rbem-44-02-e056.pdf.

5. Guariente SMM, Guariente MHDM, Moraes A. Perfil sociodemográfico do estudante ingressante no curso de graduação em medicina de 2004 a 2013: análise documental. Rev Méd Minas Gerais. 2020;30:e-30102 [access in 3 oct 2020]. Available from: http://rmmg.org/artigo/detalhes/2664.

6. Rego RM, Marques NA, Monteiro PC, Oliveira CLB, Lins NAA, Caldas CAM. O perfil atual do estudante de medicina e sua repercussão na vivência do curso. Para Res Med J. 2018;2(1-4):e05 [access in 3 oct 2020]. Available from: https://prmjournal.org/article/10.4322/prmj.2018.005/pdf/prmjournal-2-14-e05.pdf.

7. Young IM. Justice and the politics of difference. Princeton: Princeton University Press; 1990.

8. Vicente AL. Sobre la bioética iberoamericana: una paradoja. Humanidad Med. 2014;14(3):570-88.

9. Arantes V, Araújo UF, Silva MAM. Josep Maria Puig: uma vida dedicada à educação em valores. Educ Pesqui. 2019;45:e201945002001 [access in $20 \mathrm{dec}$ 2020]. Available from: https://www.revistas.usp.br/ep/article/ view/162695/156537.
10. Puig JM. Práticas morais: uma abordagem sociocultural da educação moral. São Paulo: Moderna; 2004. 200 pp. p. 62.

11. Puig JM, Araújo UF, Arantes VA. Educação em valores: pontos e contrapontos. São Paulo: Summus; 2007.

12. Puig JM. Construcción de la personalidad moral. Barcelona: Paidós; 1996.

13. Neves Júnior WA. A educação em valores e as práticas morais nas disciplinas de bioética de faculdades de medicina no Estado de São Paulo [tese]. Rio de Janeiro: Fundação Oswaldo Cruz; 2016. 143pp. p.43.

14. Hodges C, Moore S, Lockee B, Trust T, Bond A. The Difference between emergency remote teaching and online learning. Educause review. 2020 [access in 11 jul 2020]. Available from: https://er.educause.edu/ articles/2020/3/the-difference-between-emergency-remote-teachingand-online-learning.

15. Cani JB, Sandrini EGC, Soares GM, Scalzer K. Educação e Covid-19: a arte de reinventar a escola mediando a aprendizagem "prioritariamente" pelas TDIC. Revista IFES Ciência. 2020;6(1):23-39 [access in 28 jul 2020]. Available from: https://www.researchgate.net/publication/342223833 EDUCACAO_E_COVID-19_A_ARTE_DE_REINVENTAR_A_ESCOLA_ MEDIANDO_A_APRENDIZAGEM_prioritariamente_PELAS_TDIC.

16. Behar PA, Schneider D. Modelos pedagógicos e Competências em Educação a Distância: a construção do MP - CompEAD. Revista de Educação Pública. 2016;25(59/2):504-24 [access in 11 jul 2020]. Available from: https://periodicoscientificos.ufmt.br/ojs/index.php/educacaopublica/ article/view/3832.

17. Torres RM, Liu PMF. Guia prático para o uso de plataformas virtuais no ensino remoto. Belo Horizonte: UFMG; 2020 [access in 28 jul 2020]. Available from: https://www.medicina.ufmg.br/wp-content/uploads/ sites/7/2020/07/E-book-Guia-pr\%C3\%A1tico-plataformas-virtuais-3.pdf.

18. Maluf F, Garrafa V. O Core Curriculum da Unesco como base para formação em bioética. Rev Bras Educ Med. 2015;39(3):456-62. p.460.

19. Organização das Nações Unidas para a Educação, a Ciência e a Cultura. Programa de Base de Estudos sobre Bioética da Unesco. Unesco; 2015 [access in 11 jul 2020]. Available from: http://www.unesco.org/new/ fileadmin/MULTIMEDIA/FIELD/Montevideo/pdf/Bioet-CoreCurriculumPT-Parte1.pdf.

20. Grupo de Ensino e Pesquisa em Bioética. Temas bioéticos em tempos de pandemia [livro online]. Belo Horizonte: Newton; 2020 [access in 11 jul 2020]. Available from: http://www.sbbioetica.org.br/Noticia/717/ GEPBio-lanca-e-disponibiliza-a-Cartilha-Temas-Bioeticos-em-tempos-depandemia-Faca-o-download-e-consulte-o-texto-na-integra.

21. Raimondi GA, Tourinho FSV, Souza FGR, Pereira DVR, Oliveira DOPS, Rosa LM. Análise crítica das DCN à luz das diversidades: educação médica e pandemia da Covid-19. Rev Bras Educ Med. 2020;44(sup 1):e0135 [access in $20 \mathrm{dec}$ 2020]. Available from: https://www.scielo.br/scielo. php?script=sci_arttext\&pid=S0100-55022020000500801\&lng $=$ pt\&nrm $=i$ so\&tlng=pt. 